\title{
AhaP, A Quorum Quenching Acylase from Psychrobacter sp. M9-54-1 That Attenuates Pseudomonas aeruginosa and Vibrio coralliilyticus Virulence
}

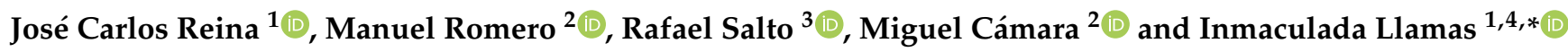 \\ 1 Department of Microbiology, Faculty of Pharmacy, Campus Universitario Cartuja s/n, University of Granada, \\ 18071 Granada, Spain; josecreina@ugr.es \\ 2 National Biofilms Innovation Centre, Biodiscovery Institute and School of Life Sciences, University of Nottingham, \\ Nottingham NG7 2RD, UK; M.Romero@nottingham.ac.uk (M.R.); Miguel.Camara@nottingham.ac.uk (M.C.) \\ 3 Department of Biochemistry, Faculty of Pharmacy, Campus Universitario Cartuja s/n, University of Granada, \\ 18071 Granada, Spain; rsalto@ugr.es \\ 4 Biomedical Research Center (CIBM), Institute of Biotechnology, University of Granada, 18100 Granada, Spain \\ * Correspondence: illamas@ugr.es
}

check for

updates

Citation: Reina, J.C.; Romero, M.; Salto, R.; Cámara, M.; Llamas, I. AhaP, A Quorum Quenching Acylase from Psychrobacter sp. M9-54-1 That Attenuates Pseudomonas aeruginosa and Vibrio coralliilyticus Virulence. Mar. Drugs 2021, 19, 16. https:// doi.org/10.3390/md19010016

Received: 7 December 2020 Accepted: 27 December 2020 Published: 1 January 2021

Publisher's Note: MDPI stays neutral with regard to jurisdictional clai$\mathrm{ms}$ in published maps and institutional affiliations.

Copyright: (C) 2021 by the authors. Licensee MDPI, Basel, Switzerland. This article is an open access article distributed under the terms and conditions of the Creative Commons Attribution (CC BY) license (https:// creativecommons.org/licenses/by/ $4.0 /)$.
Abstract: Although Psychrobacter strain M9-54-1 had been previously isolated from the microbiota of holothurians and shown to degrade quorum sensing (QS) signal molecules C6 and C10-homoserine lactone (HSL), little was known about the gene responsible for this activity. In this study, we determined the whole genome sequence of this strain and found that the full 16S rRNA sequence shares $99.78-99.66 \%$ identity with Psychrobacter pulmonis CECT $5989^{\mathrm{T}}$ and P. faecalis ISO-46 ${ }^{\mathrm{T}}$. M954-1, evaluated using the agar well diffusion assay method, showed high quorum quenching (QQ) activity against a wide range of synthetic $N$-acylhomoserine lactone (AHLs) at 4,15 , and $28^{\circ} \mathrm{C}$. Highperformance liquid chromatography-mass-spectrometry (HPLC-MS) confirmed that QQ activity was due to an AHL-acylase. The gene encoding for QQ activity in strain M9-54-1 was identified from its genome sequence whose gene product was named AhaP. Purified AhaP degraded substituted and unsubstituted AHLs from C4- to C14-HSL. Furthermore, heterologous expression of ahaP in the opportunistic pathogen Pseudomonas aeruginosa PAO1 reduced the expression of the QS-controlled gene $l e c A$, encoding for a cytotoxic galactophilic lectin and swarming motility protein. Strain M9-54-1 also reduced brine shrimp mortality caused by Vibrio coralliilyticus VibC-Oc-193, showing potential as a biocontrol agent in aquaculture.

Keywords: quorum quenching; acylase; Psychrobacter; marine habitat

\section{Introduction}

The term quorum sensing (QS), which refers to a well-known population densitydependent gene expression mechanism, was introduced for the first time by Fuqua et al. in 1994 [1]. QS enables bacteria to communicate with each other through the production, release and detection of signal molecules, also known as autoinducers. After reaching a threshold concentration in the surrounding medium, these autoinducers coordinate the expression of multiple genes, including those coding for antibiotic and exoenzyme production, as well as for biofilm formation [2-4]. Some of the most studied autoinducers produced by Gram-negative bacteria are $N$-acylhomoserine lactones (AHLs). The canonical AHL molecule contains a homoserine lactone ring linked to an acyl chain which can present different levels of saturation and substitution [5-7].

AHL-mediated QS systems control virulence gene expression in multiple pathogens, including marine, agricultural and human pathogens [8-13]. Hence, interference with QS systems has been proposed as a novel strategy to prevent or attenuate these infections [14]. This interference can be achieved using molecules that block the interaction of AHLs with their cognate signal receptors without affecting signal integrity. These molecules are 
generally named QS inhibitors (QSIs). Alternatively, QS signaling can be disrupted by enzymatic inactivation of the signal molecules, a mechanism known as quorum quenching (QQ), which is one of the most studied approaches used to interfere with QS-mediated regulatory mechanisms in order to control bacterial infections [15].

There are three main types of AHL-QQ enzymes: lactonases, which open the lactone ring; acylases, which cleave the AHL amide bond; and oxidoreductases, which modify the fatty acid chain whose recognition is impeded by the signal receptor [16,17]. Enzymatic degradation of AHLs has been reported in a wide range of microorganisms, including AHL- and non-AHL-producing bacteria [18], as well as in mammalian cells [19], suggesting that QS inhibitory processes play an important role in different environments, whose actual ultimate physiological function, however, remains unexplained [20].

QQ enzymes have been shown to be effective in preventing infections caused by AHL-producing bacterial pathogens in konjac [21], potato tubers [22-24], tobacco and cauliflower [25], and shrimps $[10,26,27]$. QQ enzymes have also been shown to reduce the virulence of the human opportunistic pathogen Pseudomonas aeruginosa in several infection models $[28,29]$. With regard to the potential use of different QQ enzyme types in the fight against infections, it has been proposed that acylases, whose AHL-degrading activity is irreversible, could be more effective than lactonases, whose degradation of AHLs can be reverted in acidic environments [30,31].

The marine environment is a prolific and valuable source of numerous bioactive compounds [32], including quorum sensing inhibitor (QSI) and QQ enzymes [33-37]. Our laboratory recently examined marine invertebrates such as sea anemones and holothurians whose microbiota are a source of antimicrobial molecules [38]. From the same collection of bacteria, several active AHL-degrading bacteria from Stenotrophomonas maltophilia isolates [24] and a QSI-producing strain of Vibrio alginolyticus [39] have been identified and characterized. In this study, we analyzed the AHL-degrading capacity of strain M9-54-1 which was isolated from a holothurian and identified as belonging to the genus Psychrobacter. The QQ activity of M9-54-1 was tested against a wide range of synthetic AHLs, as well as crude extracts from AHL-producing aquacultural and human pathogens. We identified the gene responsible for this activity and also purified and characterized the enzyme encoded by this gene. The ability of this QQ enzyme to interfere with the QS systems of the pathogens Pseudomonas aeruginosa PAO1 and Vibrio coralliilyticus VibC-Oc-193 was also evaluated.

\section{Results}

\subsection{Psychrobacter sp. M9-54-1 Shows Broad AHL-Degrading Activity}

Strain M9-54-1, belonging to Psychrobacter sp., had previously been isolated from the microbiota of Holothuria spp. [38] and selected for its ability to degrade C6-homoserine lactone (HSL) and C10-HSL. The QS interference mechanism has been reported to involve enzymatic inactivation of AHLs but not the production of QSI compounds [24]. In the present study, in order to evaluate M9-54-1 AHL-degradation activity in more detail, a wide range of AHLs, including both synthetic and crude AHL extracts, was tested using agar well diffusion assays (Figure 1). Reactions with synthetic AHLs (C4-, C6, C8-, C10-, 3-OH-C10-, $\mathrm{C} 12-$, and 3-O-C12-HSL) were carried out at 4, 15, and $28^{\circ} \mathrm{C}$; the remaining AHL signal activity was measured as the diameter of colored halos developed by Agrobacterium tumefaciens biosensor strain NTL4 (pZLR4). Strain M9-54-1 showed activity against all AHLs at most temperatures, with or without substituted groups (Figure 1). Given that alkaline $\mathrm{pH}$ has been shown to drive AHL lactonolysis [31], $\mathrm{pH}$ was measured in all cultures to ensure that it was not the cause of AHL inactivation. Since all the AHLs analyzed were completely degraded at $28^{\circ} \mathrm{C}$, the QQ activity of Psychrobacter sp. M9-54-1 was tested at this temperature against AHL crude extracts from pathogenic Vibrio spp. and Pseudomonas aeruginosa. AHLs produced by aquaculture-related pathogens $V$. owensii VibC-Oc-106 (Figure 1), V. mediterranei VibC-Oc-097, and V. coralliilyticus VibC-Oc-193 (data not shown) were found to be completely degraded by M9-54-1. In the case of AHLs produced by 
the human pathogen P. aeruginosa PAO1, incubation with M9-54-1 resulted in extensive AHL degradation.

A

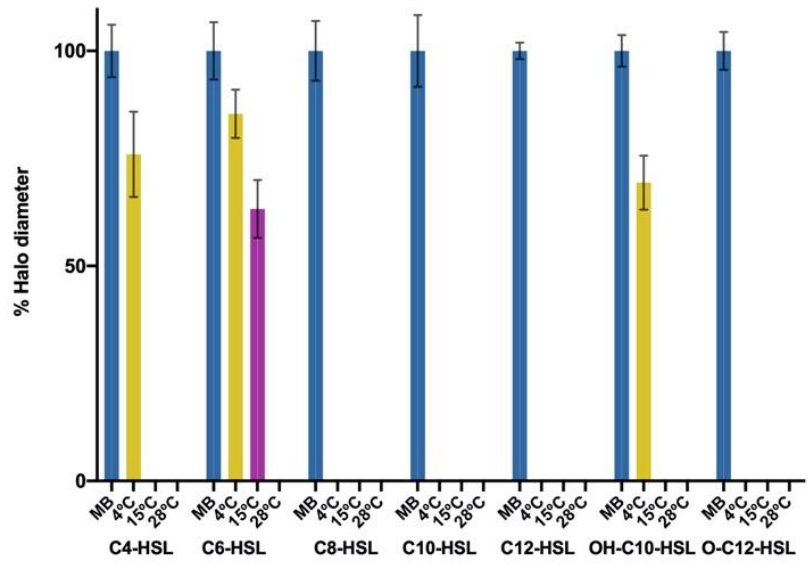

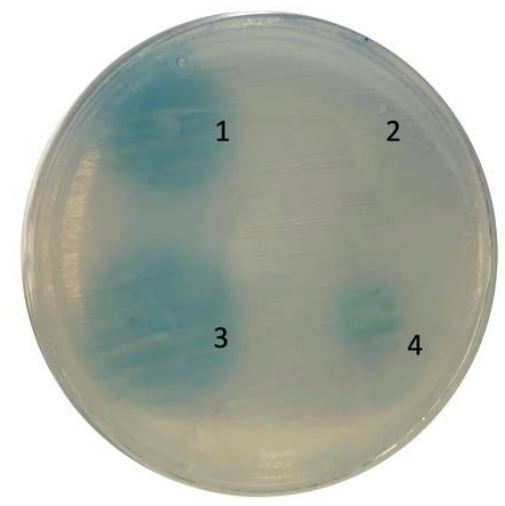

Figure 1. AHL-degradation activity of Psychrobacter sp. M9-54-1 explored using the agar plate diffusion assay method. (A) Degradation activity against synthetic AHLs, at different temperatures, expressed as percentage of halo diameter. Marine broth (MB) was used as negative control. (B) Detection of AHLs using biosensor strain Agrobacterium tumefaciens NTL4 (pZLR4): V. owensii VibC-Oc-106 crude extract (1), M9-54-1 degradation of V. owensii VibC-Oc-106 crude extract (2), $P$. aeruginosa PAO1 crude extract (3) and M9-54-1 degradation of a crude extract of P. aeruginosa PAO1 (4).

\subsection{Whole-Genome Analysis of Psychrobacter sp. M9-54-1 Shows Potential for a New Species}

With its partial 16S rRNA gene homology (99.21\% identity) but only $43.7 \%$ genome sequence completeness, strain M9-54-1 had previously been identified as Psychrobacter faecalis. In this study, the genomic DNA of Psychrobacter sp. M9-54-1 was extracted and sequenced. Draft genome assembly led to $3.2 \mathrm{~Kb}$ in 69 contigs, with an average coverage of $230 \mathrm{X}$ and $\mathrm{G}+\mathrm{C}$ content of $43.4 \mathrm{~mol} \%$. The genome was deposited in the NCBI genome database under accession number JADGFW000000000. Having obtained the whole genome sequence, we were able to identify and analyze the complete 16S rRNA gene sequence of strain M9-54-1, which shares $99.78 \%$ identity with P. pulmonis CECT $5989^{\mathrm{T}}$ and $99.66 \%$ identity with $P$. faecalis ISO- $46^{\mathrm{T}}$. The in silico DNA-DNA hybridization (DDH) and the average nucleotide identity (ANI) between strains M9-54-1 and P. faecalis SHUES1 (NZ_LXQA00000000.1), whose genome was available, were determined. The in silico DDH value was $60.4 \%$ and the ANI values based on ANIb and ANIm were 94.74 and $95.21 \%$, respectively. Both DDH and ANI results were lower than the proposed cut-off values to describe a novel species (DDH, 70\% and ANI, 95-96\%), suggesting that strain M9-54-1 is a new species of the genus Psychrobacter. Nevertheless, no definitive conclusion can be drawn until the complete genome of P. pulmonis is published and compared with that of M9-54-1.

\subsection{Psychrobacter sp. M9-54-1 AHL-Degrading Activity Is Cell-Associated and Not Due to Lactonolysis}

To determine whether the QQ activity of strain M9-54-1 is due to an AHL lactonase, an acidification assay was performed using C10-HSL, an AHL that was completely degraded by this strain. The concentration of AHLs was not restored in the acidified and filtered supernatant when they were tested by agar well diffusion assay (Figure 2A). To confirm this result, the AHL concentration was also analyzed by HPLC-MS (Figure 2B). The QQ activity of strain M9-54-1 was observed to be $100 \%$, with no recovery in AHL concentration being detected following incubation under acidic conditions. These findings suggested that the mechanism by which autoinducers are degraded was not caused by an AHL lactonase. 
A

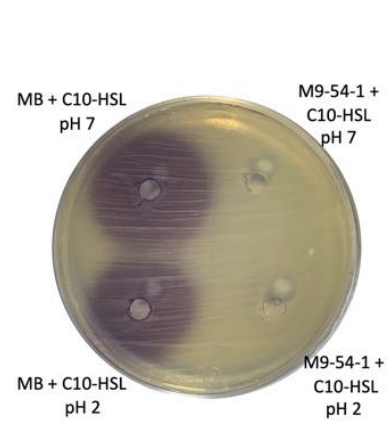

B
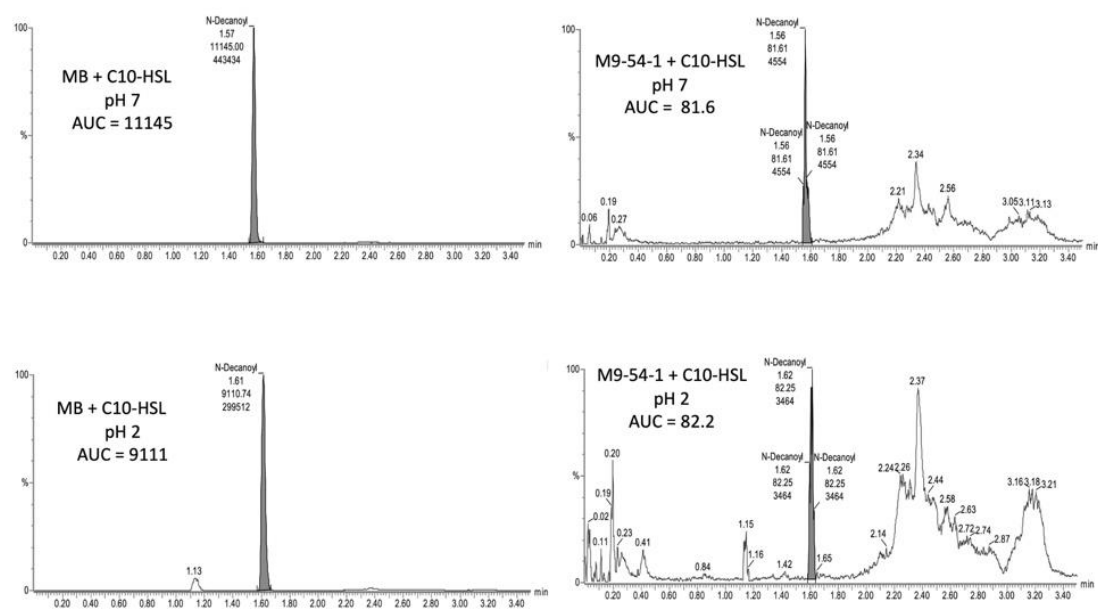

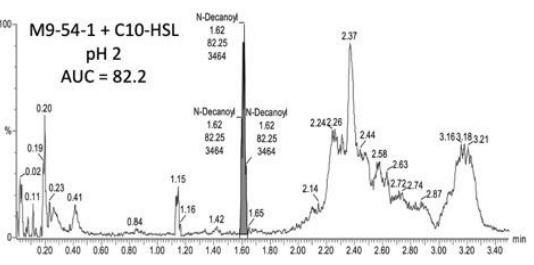

Figure 2. Detection of the remaining C10-HSL activity by agar well diffusion assay using C. violaceum VIR07 (A) and HPLC-MS (B) before and after Psychrobacter sp. M9-54-1 supernatant acidification to determine the quorum-quenching enzymatic mechanism present in this bacterium. Marine broth (MB) was used as negative control. HPLC values are referred to as area under the curve (AUC).

The cellular localization of the enzyme was also evaluated by testing C10-HSLdegrading activity in supernatants and crude cellular extracts (CCEs) from M9-54-1 cultures using the agar well diffusion assay method. QQ activity was detected in CCEs, whilst no AHL degradation activity was detected in filtered supernatants, indicating that the enzyme is not secreted (data not shown).

2.4. Genome Analysis of Strain M9-54-1 Reveals that the AhaP Gene Is a Potential Acylase with AHL-Degrading Activity

To identify the gene responsible for QQ activity in Psychrobacter sp. strain M9-54-1, a BLASTp search was carried out against a database of predicted proteins from the genome of this strain, using a group of 28 well-known QQ enzymes as queries (Supplementary Table S1). Two proteins (Nos. 2034 and 322), presented in Table 1, were found to have an e-value of under $1 \times 10^{-100}$ with different QQ enzymes, a threshold high enough to suggest that the hit could constitute a QQ enzyme.

Table 1. Homologues to quorum quenching putative proteins identified in the genome of Psychrobacter sp. M9-54-1.

\begin{tabular}{lccc}
\hline \multicolumn{1}{c}{ Homologues } & Identity (\%) & Positives (\%) & e-Value \\
\hline & Protein No. 2034 & & \\
\hline AaC Ralstonia sp. XJ12B (AAO41113.1) & 37 & 54 & $3.00 \times 10^{-171}$ \\
AaC Shewanella sp. MIB015 (BAF94155.1) & 32 & 47 & $1.00 \times 10^{-112}$ \\
AhlM Streptomyces sp. M664 (AAT68473.1) & 35 & 52 & $1.00 \times 10^{-131}$ \\
HacA Pseudomonas psyringae pv. syringae B728a (YP_235052.1) & 35 & 53 & $4.00 \times 10^{-152}$ \\
PvdQ Pseudomonas aeruginosa PAO1 NP_251075.1 & 36 & 53 & $1.00 \times 10^{-162}$ \\
\hline
\end{tabular}

Protein No. 322

Uncultured bacterium BpiB05 Bio8 (ABU51109)

40

59

$3.00 \times 10^{-159}$

The automatic annotation of the two proteins was then confirmed by RAST. Protein no. 2034 had been automatically annotated as acyl-homoserine lactone acylase PvdQ, while protein no. 322 was annotated as a hypothetical protein.

The corresponding genes $2034(2.46 \mathrm{~kb})$ and $322(1.77 \mathrm{~kb})$ were cloned into vector pGEX-4T-2, resulting in the production of pGEX-2034 and pGEX-322, respectively, and expressed in E. coli BL21 (DE3). Since only the expression of gene 2034 demonstrated an 
ability to degrade C10-HSL, as determined by the agar well diffusion assay method, gene 322 was discarded (data not shown). Protein No. 322 had homology with BpiB05, a QQ enzyme from an uncultured bacterium, and little is known about the key aminoacids for its activity, which may explain why no QQ activity was found in Protein No. 322. Thus, the protein encoded by gene 2034 was selected for further study and named acyl-homoserine lactone acylase from $\underline{P}$ sychrobacter sp. (AhaP).

The sequence of the predicted protein encoded by gene 2034 was compared with that of well-known QQ acylases with demonstrated AHL-degrading capacity using the neighbour-joining algorithm. The phylogenetic tree revealed that the enzyme AhaP from Psychrobacter sp. M9-54-1 shows high clustering similarity to other AHL acylases (Figure 3A). In fact, the predicted amino acid sequence of AhaP shared $36 \%$ identity with the amino acid sequence of PvdQ from P. aeruginosa PAO1 (NP_251075.1). As expected, the protein structure of AhaP, which was predicted using Phyre2 software, shared high similarity to that of the known acylase PvdQ from PAO1 (Figure 3B). The alignment between AhaP and PvdQ is shown in Supplementary Figure S1.

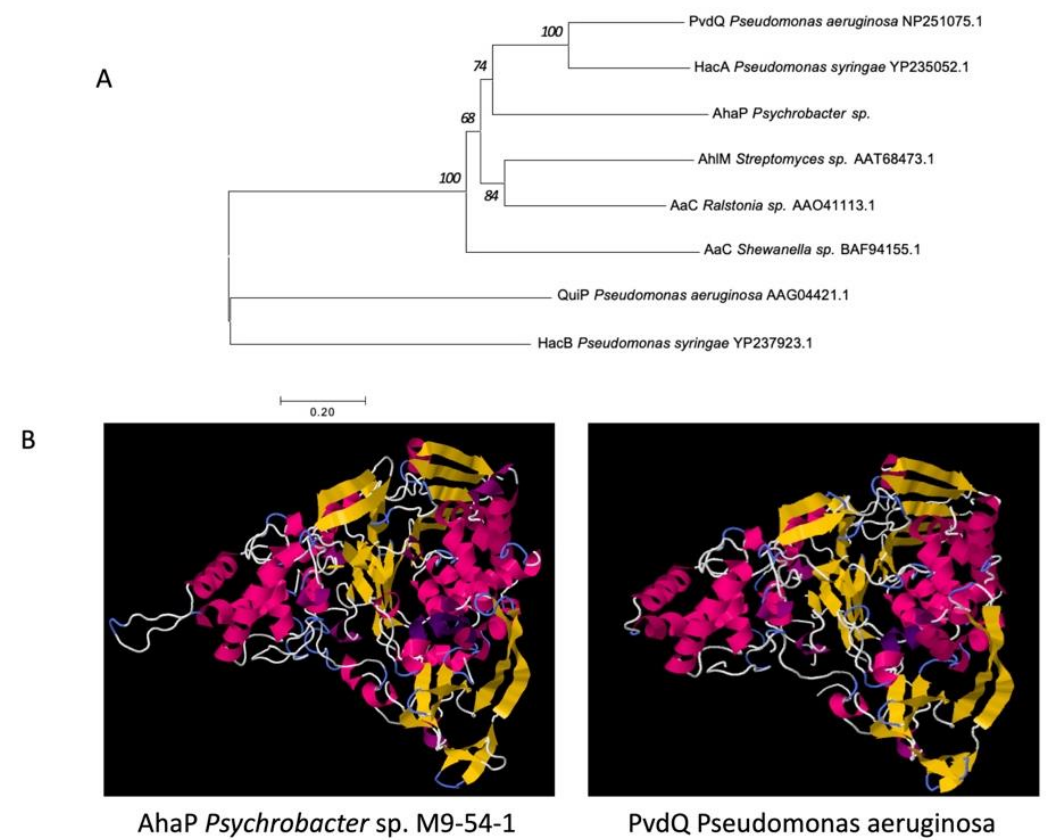

Figure 3. (A). Phylogenetic analysis of the acylase AhaP from Pyschrobacter sp. M9-54-1 and other known acylases using the neighbor-joining method with 1000 bootstrap replications. (B). Comparison of the predicted structures of the acylases AhaP from Psychrobacter sp. M9-54-1 and PvdQ from Pseudomonas aeruginosa PAO1 using the Phyre2 program.

\subsection{Purified AhaP Degrades AHLs with Different Substitutions and a Wide Range of Acyl Chain Lengths}

To facilitate the purification of AhaP, the ahaP gene was cloned into vector pET-24b (+) with a C-terminal 6xHis tag and expressed in E. coli NiCo21. The use of this construct and host should improve the solubility and increase the yield. The purified protein, which integrity was analyzed by SDS-PAGE (data not shown), was used in a QQ assay with a wide range of synthetic AHLs (C4-, O-C4-, OH-C4-, C6-, O-C6-, OH-C6-, C8-, O-C8-, OH-C8-, C10-, O-C10-, OH-C10-, C12-, O-C12-, OH-C12-, C14-, O-C14-, and OH-C14-HSL). For each AHL, the remaining signal activity was detected by using the bioluminescent biosensor strains E. coli JM109 (pSB536) for C4-HSL and its derivatives E. coli JM109 (pSB401) for C6-, C8-, and C10-HSL and their derivatives, as well as E. coli JM109 (pSB1142) for C12- and C14-HSL and their derivatives. The results obtained demonstrated the presence of AhaP QQ activity against all the AHLs tested except for O-C4-, OH-C4-, and C14-HSL (Figure 4). 

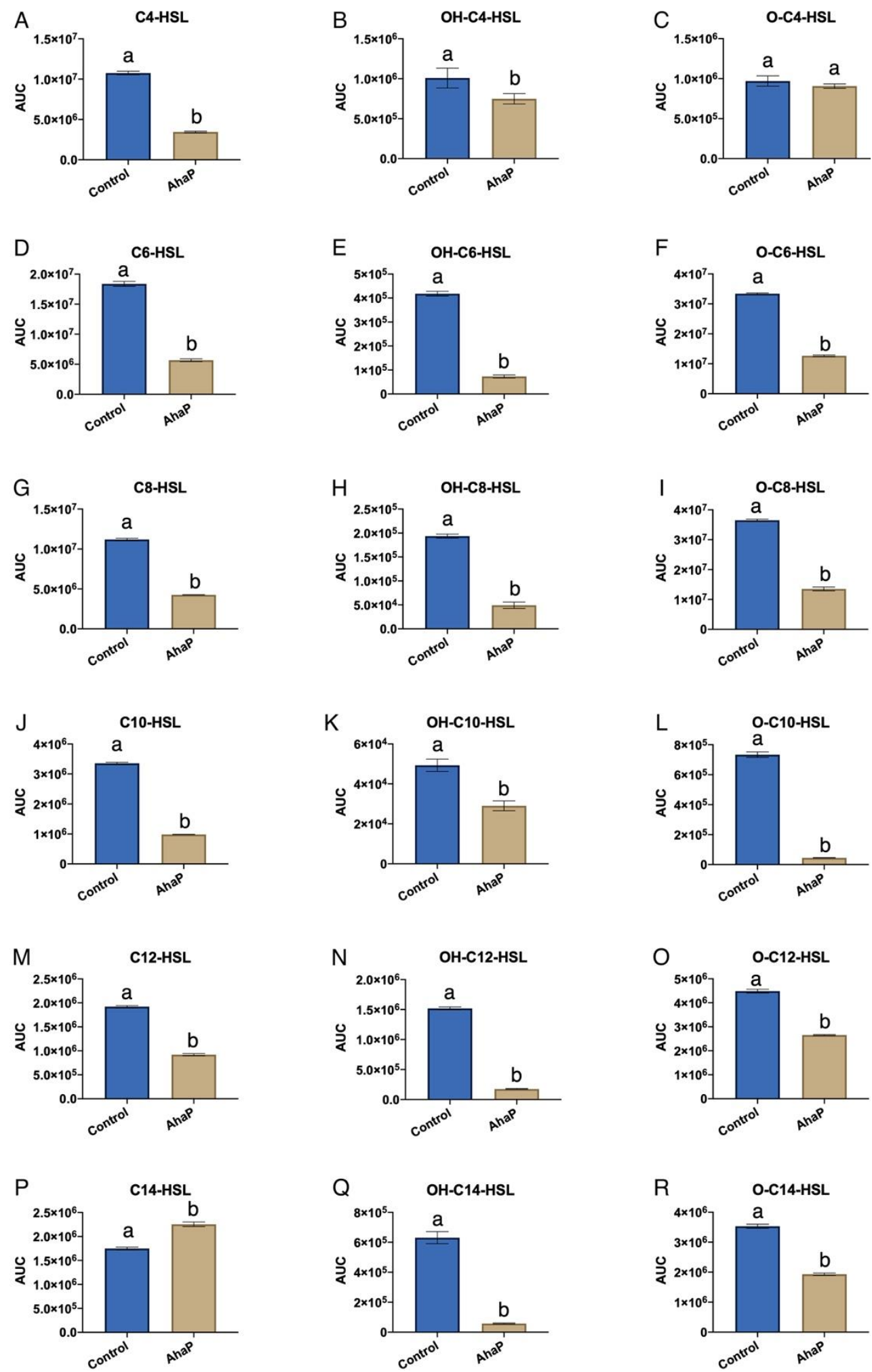

Figure 4. Quorum quenching activity of the purified enzyme AhaP against synthetic AHLs (C4-HSL (A), OH-C4-HSL (B), O-C4-HSL (C), C6-HSL (D), OH-C6-HSL (E), O-C6-HSL (F), C8-HSL (G), OH-C8-HSL (H), O-C8-HSL (I), C10-HSL (J), OH-C10-HSL (K), O-C10-HSL (L), C12-HSL (M), OH-C12-HSL (N), O-C12-HSL (O), C14-HSL (P), OH-C14-HSL (Q), O-C14-HSL (R). Autoinducer activity was detected with the biosensor strains E. coli (pSB536) for C4-HSL and its derivatives; E. coli (pSB401) for C6-, C8- and C10-HSL and their derivatives; and E. coli (pSB1142) for C12- and C14-HSL and their derivatives. Values are expressed as the area under the curve (AUC) of relative light units $/ \mathrm{OD}_{600}$. Different letters above the bars indicate that the values are significantly different $(p<0.05)$. 


\subsection{Heterologous Expression of ahaP in Pseudomonas aeruginosa Attenuates QS-Controlled Virulence Traits}

The ahaP gene was cloned into the broad host-range plasmid pME6000 and expressed in Pseudomonas aeruginosa PAO1 to evaluate its effect, if any, on phenotypes regulated by AHL-based QS systems. To this end, swarming motility of PAO1 overexpressing ahaP (pME6000::ahaP) was tested and compared to that of the same strain carrying the empty plasmid (pME6000) and the PAO1 wild type strain. As shown in Figure 5A, the expression of ahaP significantly reduced swarming motility in this opportunistic pathogen. Moreover, the pME6000::ahaP construct and empty plasmid were transferred to the biosensor strain PAO1 lecA::lux in which the expression of lectin gene lecA was evaluated. The strain's bioluminescence output without plasmid pME6000 was also assessed as control. The luminescence produced by the reporter strain was significantly reduced $(p<0.05)$ when the incubation was carried out in the presence of exogenous C4- and C6-HSL which increase the biosensor response (Figure $5 \mathrm{~B}$ ). These results indicate that AhaP enzymatic activity reduces the expression of these two virulence factors in the human pathogen P. aeruginosa PAO1.

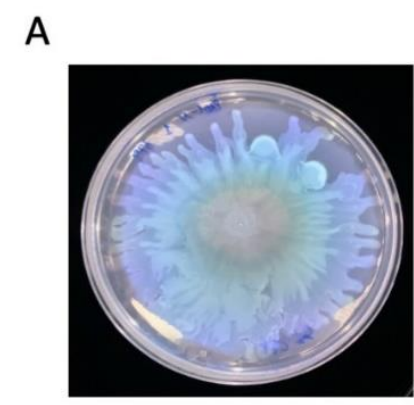

PAO1

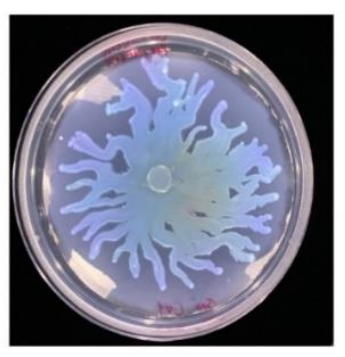

PAO1 pME6000

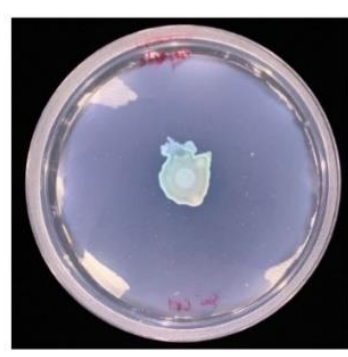

PAO1 pME6000::ahaP
B

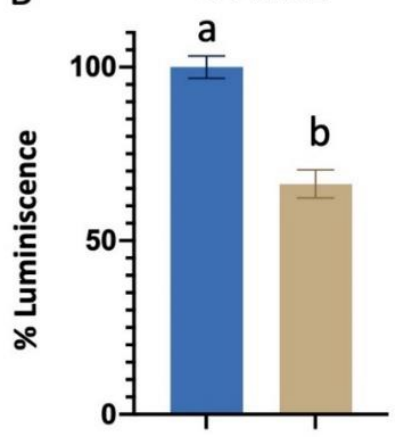

C6-HSL

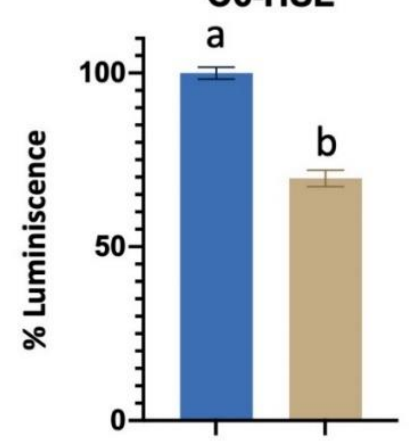

PAO1 lecA::lux pME6000 + $50 \mu \mathrm{M} \mathrm{AHL}$

PAO1 lecA::lux pME6000::ahaP + $50 \mu \mathrm{M} \mathrm{AHL}$

Figure 5. Evaluation of ahaP expression in P. aeruginosa PAO1. (A). Swarming motility assay of PAO1 wild type and strains containing the pME6000::ahaP construct and empty plasmid pME6000. (B). Detection of luminescence production in the biosensor strains PAO1 lecA::lux and PAO1 lecA::lux containing the pME6000::ahaP construct and empty plasmid pME6000 in the presence of C4- and C6-HSL. Different letters above the bars indicate that the values are significantly different $(p<0.05)$.

2.7. Psychrobacter sp. M9-54-1 Attenuates the Virulence of Vibrio Coralliilyticus VibC-Oc-193 Both In Vitro and In Vivo

Given that Psychrobacter sp. M9-54-1 abolished AHL-mediated signal activity present in crude extracts from three Vibrio spp., the V. coralliilyticus strain VibC-Oc-193 was selected to test the effect of AHL degradation by M9-54-1 on virulence factors produced by this aquaculture pathogen. Under the conditions tested, the AHLs produced by $V$. coralliilyticus VibC-Oc-193 (Figure 6A) were degraded in the presence of the M9-54-1 strain. In the 
phenotypic analyses carried out, only the production of gelatinase in $V$. coralliilyticus VibC-Oc-193 was drastically reduced (Figure 6B).

A

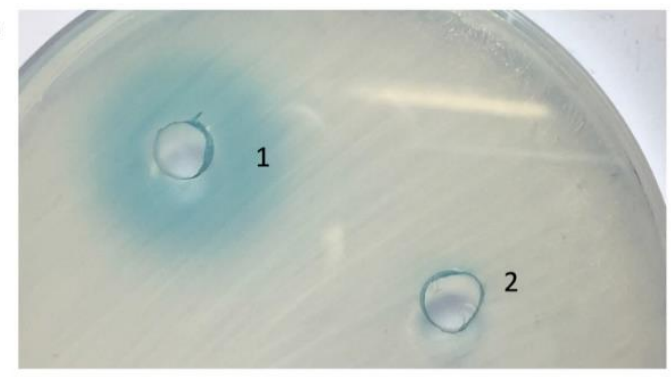

c

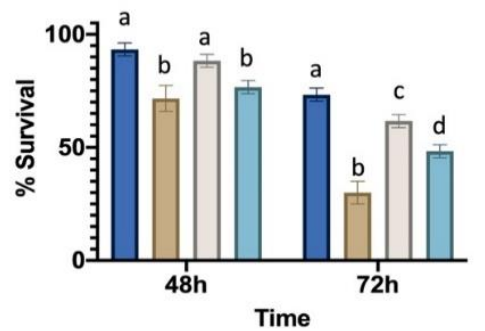

B

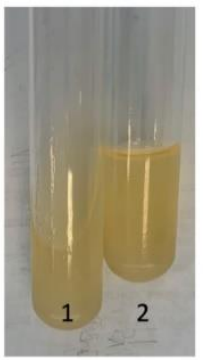

SFSW

Control V. corallilyticus

Control strain M9-54-1

Coculture M9-54-1 + V corallilyticus

Figure 6. Production of AHLs (A) and gelatinase (B) by V. coralliilyticus VibC-Oc-193 (1) and the co-culture of Psychrobacter M9-54-1 and V. coralliilyticus VibC-Oc-193 (2). (C). Survival rate of Artemia salina nauplii after $48 \mathrm{~h}$ and $72 \mathrm{~h}$ of incubation with the different cultures. Different letters indicate significant differences $(p<0.05)$.

To evaluate its potential use to control bacterial infections, we tested the QQ activity of M9-54-1 in a disease model of Artemia salina brine shrimp after 48 and $72 \mathrm{~h}$ infection with $V$. coralliilyticus VibC-Oc-193. Statistically significant disease attenuation was observed after $72 \mathrm{~h}$ of infection, resulting in an increase of $17.5 \%$ in the survival rate of Artemia salina incubated with M9-54-1 as compared to the infected Artemia salina without the Psychrobacter strain (Figure 6C).

To confirm that the reduction in virulence recorded was due to QS interference and not to a growth inhibitory effect on VibC-Oc-193, colony forming units from M9-54-1 were assessed. No differences in VibC-Oc-193 viability were observed from either culture (data not shown), suggesting that the decrease in virulence observed is likely associated with AHL degradation by M9-54-1.

\section{Discussion}

During the last decade, antimicrobial resistance (AMR) has become a serious global threat to human and animal health. International organizations such as FAO and WHO are working closely on implementing a global plan to minimize the threat of AMR which includes the development of novel strategies to fight bacterial infection diseases (www.fao. org). One novel and promising approach in which the research community is interested is interference with quorum sensing which controls virulence gene expression in numerous pathogens. The majority of studies have focused on enzymatic AHL degradation, with only a few devoted to non-enzymatic inhibitory mechanisms [14].

The marine environment has proven to be an excellent source of novel enzymes and compounds that interfere with QS systems [11,40,41]. In an attempt to discover novel QS-inhibiting compounds, we previously explored the marine symbiotic bacteria of invertebrates from which we selected AHL-degrading [24] and QSI-producing bacteria [39]. Thus, strain M9-54-1, with its high levels of AHL-degrading activity, was isolated from holothurians and selected for further study. In the present study, a cold-adapted QQ 
enzyme named AhaP, which was identified and purified from strain M9-54-1, demonstrated its ability to degrade with high levels of activity substituted and unsubstituted AHLs.

The strain M9-54-1 has been identified as belonging to the genus Psychrobacter based on the $16 \mathrm{~S}$ rRNA gene sequence and whole genome sequencing. Its full-length $16 \mathrm{~S}$ rRNA gene sequence similarity to $P$. faecalis and P. pulmonis was over $99.5 \%$, indicating that this strain could belong to either of these species. However, a whole genome comparison between M9-54-1 and P. faecalis based on digital DNA-DNA hybridization and ANI values, suggests that M9-54-1 could be a new species of the genus Psychrobacter [42]. Since the whole genome sequence of $P$. pulmonis was not available, a whole-genome comparison with this species could not be performed. Interestingly, despite high similarities amongst their 16S rRNA gene sequences, these species differ in terms of phenotypic characteristics such as carbohydrate use [43].

Most bacteria of the genus Psychrobacter are psychrotolerant, with a growth temperature ranging from -10 to $38{ }^{\circ} \mathrm{C}$, and halotolerant, showing growth in the presence of up to $6.5 \%(w / v) ~ N a C l$. Many of these bacteria are isolated from cold and high-salt environments such as Antarctic and seawater [44]. Psychrophile and psychrotolerant bacteria have become important vehicles for isolating novel high-activity enzymes at low temperatures, making them excellent energy-saving biocatalysts with a reduced environmental impact [45]. In addition, these enzymes are more thermostable than those originating from plants and animals [46].

Cold-adapted enzymes are considered to have potential biotechnological and industrial applications that require activity at mild temperatures and rapid heat inactivation rates, such as that found in molecular biology, medical research, food/feed processing, pharmaceuticals, detergents and cosmetics [45,47-49]. With regard to Psychrobacter, coldadapted enzymes, such as ribonucleases, proteases, esterases and lipases, have been found in some species of this genus $[45,47,50-52]$. Nevertheless, the production of compounds that interfere with quorum sensing (QS) in Psychrobacter strains has been the subject of a limited number of studies. For example, a marine sponge Psychrobacter sp. strain was found to degrade 3-O-C8-HSL and to be able to reduce swarming motility in Pseudomonas aeruginosa [53]. Another strain of Psychrobacter sp. isolated from a marine sponge has been reported to produce cyclic dipeptides that act as QS inhibitors via a non-enzymatic mechanism [54]. In our study, the experimental evidence presented, together with a phylogenetic analysis of the AhaP protein, suggest that the QQ enzyme produced by strain M9-54-1 belongs to a family of AHL acylases, showing high sequence and structural similarity to PvdQ from P. aeruginosa [55]. These findings reinforce the notion that the QS interference mechanism of strain M9-54-1 is not caused by the production of compounds that block the interaction of AHLs with their cognate signal receptors.

Psychrobacter sp. strain M9-54-1 has shown high levels of activity against a broad range of synthetic AHLs as well as those produced by bacterial pathogens. Thus, the potential use of AhaP enzyme to combat bacterial infections was evaluated by expressing it in the human pathogen P. aeruginosa PAO1. A recurrent problem associated with infections caused by $P$. aeruginosa is the multiple antibiotic resistance displayed by clinical isolates of this bacterium $[56,57]$, which greatly limits the treatment choices available. In this study, by using the strain P. aeruginosa PAO1 and the P. aeruginosa bioreporter PAO1 lecA::Iux, we demonstrated that ahaP gene expression interferes with the production of the carbohydratebinding protein LecA which acts as an adhesin and a cytotoxin [58]. The reduction in lecA gene expression when PAO1 cultures were spiked with AHLs, as well as swarming motility inhibition, a well-studied QS-regulated phenotype in P. aeruginosa [59], suggest the potential use of AhaP as an anti-virulence treatment technique.

Strain M9-54-1, which is a marine bacterium, was also tested as a potential biocontrol tool to combat infections in aquaculture. The QS system is known to be involved in virulence control mechanisms of Vibrio spp. whose interference has proved to be a promising strategy to control vibriosis, a bacterial disease which has a considerable impact on aquaculture $[60,61]$. Prior to the in vivo experiments, co-cultures between strain M9-54-1 
and V. coralliilyticus VibC-Oc-193 were conducted, leading to a drastic reduction in AHLs and gelatinase production in the pathogen. Other virulence factors such as enzymatic activities produced by the pathogen were also tested but no significant differences were observed. The 100:1 QQ bacterium to pathogen ratio used in the co-culture experiments in order to obtain successful results was similar to that used in previous studies $[24,37,62]$. Thus, in vivo experiments were conducted under conditions similar to those used in the co-culture assays in order to test $V$. coralliilyticus VibC-Oc-193 virulence using Artemia salina nauplii in an animal model which have been used in previous studies $[10,24,63,64]$. Strain M9-54-1 significantly reduced the mortality of Artemia salina nauplii after $72 \mathrm{~h}$ of infection with the pathogen, making it an excellent potential biocontrol agent in aquaculture.

Numerous studies have reported the effect of AHL-degrading bacteria, as well as heterologous QQ gene expression, on the reduction in the production of pathogen virulence factors in humans, aquaculture and agriculture $[11,30,65,66]$. Nevertheless, little is known about cold-adapted AHL-degrading enzymes, referred to as lactonases. For example, several cold-adapted lactonase-producing Planococcus strains isolated from Antarctica have been identified. These include the cold-adapted AHL lactonase AidP which was purified and demonstrated to attenuate the pathogenicity of Pectobacterium carotovorum [67]. Another cold-adapted AHL lactonase, named Aii810, derived from the high QQ activity Mao-tofu metagenome at low temperatures, was found to decrease virulence factors and biofilm in P. aeruginosa PAO1 [68]. In this study, a cold-adapted acylase-type QQ enzyme produced by a Psychrobacter strain has been characterized for the first time. Cold-adapted enzymes used as biotechnological tools, which are cost-effective and catalyze reactions at low temperatures, offer advantages over their mesophilic homologues, by reducing bacterial contamination and slowing down undesirable chemical reactions. Moreover, many of these thermolabile enzymes can be inactivated by moderate heat instead of chemical-based treatment [47].

In conclusion, in this study, a cold-adapted acylase enzyme named AhaP from M954-1, a marine strain of the genus Psychrobacter, has been identified for the first time. After purification, this enzyme showed high levels of activity against a broad range of AHLs and significantly reduced the production of virulence factors in P. aeruginosa. In vivo assays also demonstrated that M9-54-1 reduces the virulence of V. coralliilyticus VibC-Oc-193, increasing the survival rate of $A$. salina infected with this pathogen by $17.5 \%$. This result reinforces the potential of using strain M9-54-1 as a biocontrol agent to combat vibriosis in aquaculture.

\section{Materials and Methods}

\subsection{Bacterial Strains, Media and Culture Conditions}

The strain M9-54-1 was routinely grown at $28^{\circ} \mathrm{C}$ in marine broth (MB, BD Difco ${ }^{\circledR}$, Franklin Lakes, NJ, USA). The biosensor strain Agrobacterium tumefaciens NTL4 (pZLR4) [69] was cultured at $28{ }^{\circ} \mathrm{C}$ in Luria-Bertani (LB) medium supplemented with $2.5 \mathrm{mmol} \mathrm{L}^{-1}$ $\mathrm{CaCl}_{2}$ and $2.5 \mathrm{mmol} \mathrm{L}^{-1} \mathrm{MgSO}_{4}(\mathrm{LB} / \mathrm{MC})$ or $\mathrm{AB}$ medium $\left(3 \mathrm{~g} \mathrm{~K}_{2} \mathrm{HPO}_{4}, 1 \mathrm{~g} \mathrm{Na}_{2} \mathrm{H}_{2} \mathrm{PO}_{4}, 1 \mathrm{~g}\right.$ $\mathrm{NH}_{4} \mathrm{Cl}, 0.3 \mathrm{~g} \mathrm{MgSO}_{4} \cdot 7 \mathrm{H}_{2} \mathrm{O}, 0.15 \mathrm{~g} \mathrm{KCl}, 0.01 \mathrm{~g} \mathrm{CaCl}_{2}, 0.0025 \mathrm{~g} \mathrm{FeSO}_{4} \cdot 7 \mathrm{H}_{2} \mathrm{O}$ and $5 \mathrm{~g}$ glucose per liter) containing $50 \mu \mathrm{g}$ gentamycin $\mathrm{mL}^{-1}$. Chromobacterium violaceum $\mathrm{CV} 026$ [70] and $\mathrm{C}$. violaceum VIR07 [71] were grown at $28^{\circ} \mathrm{C}$ in LB medium supplemented with kanamycin $\left(50 \mu \mathrm{g} \mathrm{mL}^{-1}\right)$. The biosensor strains Escherichia coli JM109 (pSB536), E. coli JM109 (pSB401) and E. coli JM109 (pSB1142) [72] were grown in the presence of ampicillin $\left(100 \mu \mathrm{g} \mathrm{mL}{ }^{-1}\right)$ or tetracycline (20 or $10 \mu \mathrm{g} \mathrm{mL}^{-1}$ ) as required [72].

The AHL-producing bacteria used for in vitro and in vivo tests were Pseudomonas aeruginosa PAO1 [73] and the aquaculture-related pathogenic species Vibrio mediterranei VibC-Oc-097, V. owensii VibC-Oc-106 and V. coralliilyticus VibC-Oc-193 [10,74]. P. aeruginosa $\mathrm{PAO} 1$ was grown in $\mathrm{LB}$ at $37^{\circ} \mathrm{C}$ and Vibrio species were grown in $\mathrm{MB}$ at $28^{\circ} \mathrm{C}$. 


\subsection{QQ Activity upon Synthetic AHLs and Crude AHL Extracts from Pathogenic Bacteria}

The capacity of M9-54-1 to degrade a wide range of synthetic AHLs as well as crude AHL extracts from pathogenic bacteria was studied using agar well diffusion assays [34,37]. The synthetic AHLs used were C4-HSL (N-butyryl-DL-homoserine lactone), C6-HSL (Nhexanoyl-DL-homoserine lactone), C8-HSL (N-octanoyl-DL-homoserine lactone), C10HSL ( $N$-decanoyl-DL-homoserine lactone), 3-OH-C10-HSL (N-3-hydroxydecanoyl-DLhomoserine lactone), C12-HSL ( $\mathrm{N}$-dodecanoyl-DL-homoserine-lactone) and 3-O-C12-HSL (N-3-oxo-dodecanoyl-DL-homoserinelactone) (Sigma ${ }^{\circledR}$, St. Louis, Missouri, USA). These AHLs were added to $500 \mu \mathrm{L}$ of a $24 \mathrm{~h}$ culture of strain M9-54-1, at a final concentration of $10 \mu \mathrm{M}$. After $24 \mathrm{~h}$ of incubation at different temperatures $\left(4,15\right.$ and $\left.28^{\circ} \mathrm{C}\right)$, the remaining signals were detected by loading $100 \mu \mathrm{L}$ of cell-free supernatant in agar plate wells seeded with the AHL biosensor strains. A. tumefaciens NTL4 (pZLR4) and AB agar plates supplemented with $80 \mu \mathrm{g} \mathrm{mL}^{-1}$ of 5-bromo-4-chloro-3-indolyl-B-D-galactopyranoside (X-Gal) were used to detect C12-HSL and 3-O-C12-HSL activity; $\mathrm{C}$. violaceum CV026 and VIR07 strains were used to detect C4-HSL, C6-HSL, C8-HSL, C10-HSL and 3-OH-C10-HSL signals.

To prepare AHL extracts from pathogenic vibrios or P. aeruginosa PAO1, a previously described methodology was followed [75,76]. Briefly, $500 \mu \mathrm{L}$ of $24 \mathrm{~h}$ cultures of each AHLproducing pathogenic bacterium were extracted twice with one volume of dichloromethane or acidified ethyl acetate. The extract was dried and resuspended in 20 or $50 \mu \mathrm{L}$ of methanol $70 \%(v / v)$. Crude extracts were then stored at $-20^{\circ} \mathrm{C}$ prior to testing.

To evaluate the ability of M9-54-1 to degrade AHL signals present in extracts from Vibrio spp. and P. aeruginosa PAO1, $5 \mu \mathrm{L}$ of the AHL crude extracts were added to $1 \mathrm{~mL}$ of an overnight culture of M9-54-1. After $24 \mathrm{~h}$ of incubation, the remaining AHLs were extracted twice with one volume of dichloromethane, dried and resuspended in $20 \mu \mathrm{L}$ of methanol $70 \%(v / v)$. These extracts were spotted onto Whatman ${ }^{\circledR}$ (GE Healthcare, Chicago, $\mathrm{IL}, \mathrm{USA}$ ) sterile disks placed in $\mathrm{AB}$ agar plates supplemented with X-Gal in which an A. tumefaciens NTL4 (pZLR4) lawn had been previously seeded. After $24 \mathrm{~h}$ of incubation, the appearance of blue halos was visually inspected.

\subsection{Identification of the Type and Location of $Q Q$ Activity}

An acidification assay [31,77] was carried out to determine whether the QQ activity of M9-54-1 was due to a lactonase mechanism. Briefly, C10-HSL was added to $500 \mu \mathrm{L}$ of a $24 \mathrm{~h}$ culture of M9-54-1 at a final concentration of $10 \mu \mathrm{M}$. After $24 \mathrm{~h}$ of incubation, the mixtures were centrifuged and the $\mathrm{pH}$ of the supernatants was adjusted to 2.0 with $\mathrm{HCl} 1 \mathrm{~N}$. Acidified supernatants were then incubated at $28^{\circ} \mathrm{C}$ for $24 \mathrm{~h}$ and the presence of AHL activity in dichloromethane extracts from the reaction mixtures was assessed using $C$. violaceum CV026.

To identify the cellular localization of AHL QQ activity present in M9-54-1, supernatants and crude cellular extract (CCE) fractions from $24 \mathrm{~h}$ cultures of M9-54-1 were obtained and assayed for QQ activity as described previously [78]. The CCEs were obtained by centrifugation, resuspension of the pellet in PBS buffer ( $\mathrm{pH}$ 6.5) and sonication of the suspension for $5 \mathrm{~min}$. Afterwards, the CCEs and culture supernatants were filtered through a $0.22-\mu \mathrm{m}$ pore membrane filter. A QQ assay was carried out with these two fractions as described in Section 2.2.

\subsection{Detection of AHL Degradation Activity by HPLC-MS}

The AHL QQ activity of Psychrobacter strain M9-54-1 against C10-HSL was studied using HPLC-MS according to a previously described methodology [36]. The QQ reaction was performed as described in Section 2.2 and the remaining signal was extracted twice in $500 \mu \mathrm{L}$ of dichloromethane, with or without prior acidification as described in Section 2.3. Dried extracts were then resuspended in $500 \mu \mathrm{L}$ of acetonitrile and analyzed by HPLC-MS. 


\subsection{DNA Extraction and Whole-Genome Sequencing Analysis}

The genomic DNA of strain M9-54-1, which was extracted using a methodology described elsewhere [79], was sequenced at the STAB Vida facility (Caparica, Portugal) using Illumina Mi-Seq technology. The low-quality bases and adaptors were trimmed using the bbduk program (https://jgi.doe.gov/data-and-tools/bbtools/) and the reads were assembled using Spades v3.11. Digital DNA-DNA hybridization was calculated using the DSMZ web server (http:/ /ggdc.dsmz.de) [80], while ANIb and ANIm calculations were performed on the JSpeciesWS website [81].

To search for potential QQ enzymes, the whole genome of strain M9-54-1 was annotated using RAST [82,83] and genes encoding potential QQ enzymes were selected using BLASTp [84] and a database of 28 QQ enzymes as queries (Supplementary Table S1).

\subsection{Cloning of Genes Encoding Quorum Quenching Activity}

Potential QQ genes identified in the genome of Psychrobacter sp. strain M9-54-1 were amplified using Q5 HF DNA polymerase (New England BioLabs ${ }^{\circledR}$, Hitchin, UK) with primers including Bam $\mathrm{H1}$ and Sal1 sites: 2034-F/R 5'-GGATCCATGAGCATTAATGTGCTT AATC-3' $/ 5^{\prime}$-GTCGACCTATTC TCTCAATTTGATCACT-3' , and 322-F/R 5'-GGATCCATG ACAAAAATAATCGACTA- $3^{\prime} / 5^{\prime}$-GTCGACTTAACGATTAAGTAAATCTGTG- ${ }^{\prime}$. PCR products were purified and cloned into pGEM-T Easy Vector (Promega ${ }^{\circledR}$, Fitchburg, WI, USA) according to the manufacturer's recommendations. The vector was transferred to Escherichia coli DH5 $\alpha$ and extracted using the New England Biolabs ${ }^{\circledR}$ Monarch Miniprep Kit. The pGEM-T vector carrying the insert, as well as the pGEX-4T-2 plasmid, were digested using the above-mentioned restriction enzymes, and the inserts were ligated in the expression vector pGEX-4T-2. This expression vector was transformed in E. coli BL21 (DE3) and clone activity was tested using the agar well diffusion assay as previously mentioned (Table 2).

The amino acid sequence of the putative AHL-acylase encoded by gene 2034 of M9-541 and sequences from other known acylases were used to build a phylogenetic tree using MEGA7 software [85]. Phyre2 was used to predict the structure of QQ enzymes [86].

Table 2. Bacterial strains and plasmids used in this study.

\begin{tabular}{|c|c|c|}
\hline Strain or Plasmid & Genotype or Description & Source or Reference \\
\hline \multicolumn{3}{|l|}{ Strains } \\
\hline Escherichia coli & & \\
\hline $\mathrm{DH} 5 \alpha$ & relA1, lacZ $\Delta \mathrm{M} 15$, supE44, thi-1 & [87] \\
\hline XL1-Blue & $\begin{array}{l}\text { supE44 hsdR17 recA1 endA1 ggyrA46 thi relA1 lac- } \mathrm{F}^{\prime} \\
\left.\left(\text { proAB } \text { lac }^{\mathrm{q}} \text { lacZDM15 Tn10 (tet }{ }^{\mathrm{r}}\right)\right)\end{array}$ & {$[88]$} \\
\hline BL21(DE3) pLysS & $\mathrm{Cm}^{\mathrm{R}}, d c m$ omp $\mathrm{T} h s d S$ gal $\lambda(\mathrm{DE} 3)$ & Promega ${ }^{\circledR}$ \\
\hline $\mathrm{NiCo} 21$ (DE3) & $\begin{array}{l}\text { can::CBD fhuA2 [lon] ompT gal ( } \lambda \text { DE3) [dcm] arnA::CBD slyD::CBD glmS6Ala } \\
\Delta h s d S \lambda D E 3=\lambda \text { sBamHIo } \Delta E c \text { ERI-B int::(lacI::PlacUV5::T7 gene1) i21 } \Delta \text { nin } 5\end{array}$ & $\begin{array}{l}\text { New England } \\
\text { Biolabs }^{\circledR}\end{array}$ \\
\hline \multicolumn{3}{|l|}{ Pseudomonas aeruginosa } \\
\hline PAO1 & Wild type & [73] \\
\hline \multicolumn{2}{|l|}{ Plasmids } & [58] \\
\hline pGEM-T & High-copy-number cloning vector, $\mathrm{Ap}^{\mathrm{R}}$, bla, lacZ & Promega ${ }^{\circledR}$ \\
\hline pG2034 & $\begin{array}{l}\text { pGEM-T with a 2.46-kb PCR BamH1-Sal1 fragment amplified from strain } \\
\text { M9-54-1 genome containing gene-encoding protein No.2034, } \mathrm{Ap}^{\mathrm{R}}\end{array}$ & This work \\
\hline pG322 & $\begin{array}{l}\text { pGEM-T with a 1.77-kb PCR Bam H1-Sal1 fragment amplified from strain M9-4-1 } \\
\text { genome containing gene-encoding protein No.233, } \mathrm{Ap}^{\mathrm{R}}\end{array}$ & This work \\
\hline pGEX-4T-2 & Glutathione-S-transferase fusion vector, $\mathrm{Ap}^{\mathrm{R}}$ & GE-Healthcare ${ }^{\circledR}$ \\
\hline pGEX-2034 & $\begin{array}{c}\text { pGEM-4T-2 with a 2.46-kb BamHI-SalI fragment containing gene-encoding } \\
\text { protein No.2034, } \mathrm{Ap}^{\mathrm{R}}\end{array}$ & This work \\
\hline pGEX-233 & $\begin{array}{l}\text { pGEM-4T-2 with 1.77-kb BamHI-SalI fragment containing gene-encoding protein } \\
\qquad \text { No.233, } \mathrm{Ap}^{\mathrm{R}}\end{array}$ & This work \\
\hline pET-24b (+) & Cloning vector carrying a C-terminal His-Tag ${ }^{\circledR}$ sequence, $A p^{R}, \mathrm{Km}^{\mathrm{R}}$ & Novagen ${ }^{\circledR}$ \\
\hline pET-24b(+)::ahaP & pET24b $(+)$ containing ahaP & This work \\
\hline pME6000 & Broad-host-range expression vector, $\mathrm{Tc}^{\mathrm{R}}$ & [89] \\
\hline pME6000::ahaP & pME6000 containing ahaP & This study \\
\hline
\end{tabular}




\subsection{Expression and Purification of Recombinant ahaP}

The ahaP gene was amplified with the primers including $\mathrm{BamH1}$ and Xho1 sites: ahaPF/R 5' TATGGATCCGTGTTCGGATAACGACAATTTTA3 ${ }^{\prime}$ / 5'TATCTCGAGTTCTCTCAA TTTGATCACTTCA $3^{\prime}$. The purified insert was digested with the indicated restriction enzymes, ligated in pET-24b(+) and transformed into E. coli NiCo21 (DE3), which is specially designed for the expression of histidine-tagged recombinant proteins (Table 2).

$500 \mathrm{~mL}$ of LB were inoculated with $10 \mathrm{~mL}$ of a $24 \mathrm{~h}$ culture of E. coli NiCo21 (DE3) (pET$24 \mathrm{~b}(+):: a h a P)$ and incubated at $37^{\circ} \mathrm{C}$. Once $\mathrm{OD}_{600}$ reached 0.6 , the culture was induced with $1 \mathrm{mM}$ IPTG and further incubated for $5 \mathrm{~h}$ at $37^{\circ} \mathrm{C}$. The pellet obtained by centrifugation was stored at $-80^{\circ} \mathrm{C}$ prior to AhaP purification using the Ni-NTA Fast Start Kit (Qiagen ${ }^{\circledR}$ ). The integrity of the purified protein was analyzed by SDS-PAGE and stored at $-20{ }^{\circ} \mathrm{C}$ until use.

\subsection{Detection of AHL Degradation Activity of AhaP}

$50 \mu \mathrm{L}$ of purified AhaP enzyme at concentration $0.5 \mathrm{mg} / \mathrm{mL}$ were added to $450 \mu \mathrm{L}$ of PBS supplemented with $5 \mu \mathrm{M}$ of each of the following AHLs: C4-HSL ( $N$-butyryl-L-homoserine lactone), O-C4-HSL (N-3-oxo-butyryl-L-homoserine lactone), OH-C4-HSL (N-hydroxybutyrylL-homoserine lactone), C6-HSL ( $N$-hexanoyl-L-homoserine lactone), O-C6-HSL (N-3-oxohexanoyl-L-homoserine lactone), OH-C6-HSL ( $N$-hydroxy hexanoyl-L-homoserine lactone), C8-HSL (N-octanoyl-L-homoserine lactone), O-C8-HSL (N-3-oxo-octanoyl-L-homoserine lactone), OH-C8-HSL ( $N$-hydroxyoctanoyl-L-homoserine lactone), C10-HSL ( $N$-decanoyl-Lhomoserine lactone), O-C10-HSL (N-3-oxo-decanoyl-L-homoserine lactone), 3-OH-C10-HSL ( $\mathrm{N}$-3-hydroxydecanoyl-L-homoserine lactone), C12-HSL ( $\mathrm{N}$-dodecanoyl-L-homoserinelactone), 3-O-C12-HSL (N-3-oxo-dodecanoyl-L-homoserine lactone), 3-OH-C12-HSL ( N3-hydroxydodecanoyl-L-homoserine lactone), C14-HSL (N-tetradecanoyl-L-homoserinelactone), 3-O-C14-HSL (N-3-oxo-tetradecanoyl-L-homoserine lactone) and 3-OH-C14-HSL ( $N$-3-hydroxytetradecanoyl-L-homoserine lactone). AHLs were synthesized at the University of Nottingham. PBS without added enzyme was used as control.

Reactions were incubated overnight at $37^{\circ} \mathrm{C}$ and $20 \mu \mathrm{L}$ were mixed with $80 \mu \mathrm{L}$ of fresh LB and loaded into 96-well plates. $100 \mu \mathrm{L}$ of a subculture $\left(\mathrm{OD}_{600}=0.01\right)$ of the biosensors E. coli JM109 pSB536 was used for detection of C4-, O-C4- and OH-C4-HSL; E. coli JM109 pSB401 for C6-, O-C6-, OH-C6-, C8-, O-C8-, and OH-C8-HSL; and E. coli JM109 pSB1142 for long chain AHLs. Absorbance at $600 \mathrm{~nm}$ and luminescence of each well were recorded for $24 \mathrm{~h}$ and the AUC of relative luminescence ratios (light units $/ \mathrm{OD}_{600}$ ) was calculated. The assay was carried out in triplicate.

\subsection{AHL-Acylase Gene Expression in Pseudomonas Aeruginosa PAO1}

The AHL-acylase gene ahaP of strain M9-54-1 was ligated into the broad-host-range plasmid pME6000. The DNA construct and the empty plasmid were then transformed in wild type P. aeruginosa $\mathrm{PAO} 1$ and in P. aeruginosa $\mathrm{PAO}$ lecA::lux, a reporter strain regulated by QS [58] (Table 2).

Swarming motility assays were performed using freshly prepared agar plates of swarming media (Nutrient Broth No.2 $0.8 \% w / v$, glucose $0.5 \% w / v$, agar $0.5 \% w / v$ ). The wild type strain PAO1 without plasmid pME6000 was used as control. A subculture with an $\mathrm{OD}_{600}=0.5$ of PAO1 ${ }^{\mathrm{WT}}$, PAO1 (pME6000), and PAO1 (pME6000::ahaP) was prepared and $3 \mu \mathrm{L}$ of the subcultures were inoculated in the center of the plates and incubated at $37^{\circ} \mathrm{C}$ overnight to evaluate swarming motility.

In the case of $P$. aeruginosa PAO1 lec A::lux, a subculture in LB with $\mathrm{OD}_{600}=0.02$ of $P$. aeruginosa PAO1 lecA::lux, P. aeruginosa PAO1 lecA::lux (pME6000) and P. aeruginosa PAO1 lecA::Iux (pME6000::ahaP) was prepared and supplemented with C4 or C6-HSL at different concentrations. They were placed in 96-well plates with black walls, and $\mathrm{OD}_{600}$ absorbance and luminescence were recorded every $30 \mathrm{~min}$. After $24 \mathrm{~h}$ of incubation, the AUC of the $\mathrm{RLU} / \mathrm{OD}_{600}$ ratio was calculated. 


\subsection{In Vitro Co-Culture Assays}

Co-culture assays were carried out with Psychrobacter strain M9-54-1 and pathogenic Vibrio spp. [24]. Briefly, $50 \mu \mathrm{L}$ of a $24 \mathrm{~h}$ culture of the pathogen were added to $5 \mathrm{~mL}$ of a $24 \mathrm{~h}$ culture of Psychrobacter M9-54-1. After $24 \mathrm{~h}$ of co-incubation, AHLs produced in the co-cultures were detected using the well-diffusion assay method as described above. To evaluate the interference of Psychrobacter M9-54-1 with virulence factor expression in the pathogenic strain, co-cultures were tested for a diverse range of enzymatic activities by spotting $10 \mu \mathrm{L}$ of the co-cultures on different media. Proteolytic and haemolytic activity was determined in casein medium and in blood agar medium, respectively [90]. Acid phosphatase activity was determined in PVK medium [91], whilst alkaline phosphatase was determined with MA or LB supplemented with phenolphthalein phosphate $0.01 \%(w / v)$ [92]. Amylase activity was determined in MA supplemented with starch $1 \%$ $(w / v)$ [93]. Gelatinase activity was detected using a gelatin medium (BD Difco ${ }^{\circledR}$, Franklin Lakes, NJ, USA). The hydrolysis of esculin was tested in MA supplemented with $0.5 \%$ $(w / v)$ esculin and $0.05 \%(w / v)$ ferric chloride added [94].

\subsection{In Vivo Assays against Vibrio Coralliilyticus}

The virulence of $V$. coralliilyticus VibC-Oc-193 in the absence and presence of strain M9-54-1 was tested in vivo in Artemia salina (brine shrimp) nauplii according to a protocol described elsewhere [10,24]. Briefly, the hatching cysts of $A$. salina (JBL Artemio Pur, JBL GmbH \& Co. KG, Neuhofen, Germany) were obtained according to the manufacturer's instructions using sterile-filtered and autoclaved seawater (SFSW) (salinity $36 \mathrm{~g} \mathrm{~L}^{-1}, 20^{\circ} \mathrm{C}$, $\mathrm{pH}$ 7.3), and groups of 20 nauplii were transferred to petri dishes containing $20 \mathrm{~mL}$ of SFSW. Then, co-cultures were made with $5 \mathrm{~mL}$ of 24-h culture of M9-54-1 to which $50 \mu \mathrm{L}$ of a $24 \mathrm{~h}$ culture of $V$. coralliilyticus were added. As controls, monocultures of strain M9-54-1, $V$. coralliilyticus and the same volume of SFSW were used. For each condition, the bacterial cells were washed with SFSW and added to the shrimp larvae in a final concentration of $10^{6} \mathrm{CFU} \mathrm{mL}{ }^{-1}$, with cell number determined by the plate counting method, and were then incubated at $25^{\circ} \mathrm{C}$ for 3 days. Each condition was done in triplicate. The survival of the shrimps, detected by loss of motility, was scored daily after the addition of bacteria. All results were analyzed using the ANOVA test $(p<0.05)$ followed by Tukey's $t$-test using $R$ software (3.6.2) (The R Foundation, Vienna, Austria).

Supplementary Materials: The following material is available online at https:/ /www.mdpi.com/ 1660-3397/19/1/16/s1, Table S1: Quorum quenching enzymes used in this study as queries in the BLASTp search for the identification of the QQ enzyme in Psychrobacter sp. M9-54-1. Supplementary Figure S1. Alignment of the protein sequences of AhaP from Psychrobacter sp. M9-54-1 and PvdQ (NP_251075.1) from Pseudomonas aeruginosa PAO1.

Author Contributions: Conceptualization, J.C.R. and I.L.; methodology, J.C.R., R.S., M.R., M.C., and I.L.; formal analysis, J.C.R., R.S., M.R., M.C., and I.L.; investigation, J.C.R., R.S., M.R., M.C., and I.L.; resources, I.L.; data curation, J.C.R., R.S., M.R., M.C., and I.L.; writing-original draft preparation, J.C.R. and I.L.; writing-review and editing, J.C.R., M.R., and I.L.; visualization, I.L., R.S., and M.C.; supervision, I.L., R.S., and M.C.; project administration, I.L.; funding acquisition, M.C. and I.L. All authors have read and agreed to the published version of the manuscript.

Funding: This research was funded by grants from the Spanish Ministry of the Economy and Competitiveness (AGL2015-68806-R and PID2019-106704RB-100/SRA) and the State Research Agency (AEI) (10.13039/501100011033). J.C.R. holds an FPU fellowship (FPU15/01717) from the Spanish Ministry of Education, Culture and Sport. M.C. and M.R. are funded by the National Biofilms Innovation Centre (NBIC), an Innovation and Knowledge Centre funded by the Biotechnology and Biological Sciences Research Council, InnovateUK and Hartree Centre (Award Number BB/R012415/1).

Institutional Review Board Statement: Not applicable.

Informed Consent Statement: Not applicable.

Data Availability Statement: The data presented in this study are fully available in the main text and Supplementary Materials of this article. 
Acknowledgments: The paper was corrected by Michael O'Shea.

Conflicts of Interest: The authors declare no conflict of interest.

\section{References}

1. Fuqua, C.; Winans, S.C.; Greenberg, E.P. Quorum sensing in bacteria: The LuxR-LuxI family of cell density-responsive transcriptional regulators. J. Bacteriol. 1994, 176, 269-275. [CrossRef]

2. Whiteley, M.; Diggle, S.P.; Greenberg, E.P.; Wilson, E.O. Bacterial quorum sensing: The progress and promise of an emerging research area. Nature 2017, 551, 313-320. [CrossRef]

3. Papenfort, K.; Bassler, B.L. Quorum sensing signal-response systems in Gram-negative bacteria. Nat. Rev. Microbiol. 2016, 14, 576-588. [CrossRef]

4. Abisado, R.G.; Benomar, S.; Klaus, J.R.; Dandekar, A.A.; Chandler, J.R. Bacterial quorum sensing and microbial community interactions. MBio 2018, 9, 1-13. [CrossRef]

5. Williams, P.; Winzer, K.; Chan, W.C.; Camara, M. Look who's talking: Communication and quorum sensing in the bacterial world. Philos. Trans. R. Soc. B Biol. Sci. 2007, 362, 1119-1134. [CrossRef]

6. Ng, W.-L.; Bassler, B.L. Bacterial quorum-sensing network architectures. Annu. Rev. Genet. 2009, 43, 197-222. [CrossRef]

7. Parker, C.T.; Sperandio, V. Cell-to-cell signalling during pathogenesis. Cell. Microbiol. 2009, 11, 363-369. [CrossRef]

8. De Kievit, T.R.; Iglewski, B.H. Bacterial quorum sensing in pathogenic relationships. Infect. Immun. 2000, 68, 4839-4849. [CrossRef]

9. Quiñones, B.; Dulla, G.; Lindow, S.E. Exopolysaccharide Production, Motility, and Virulence in Pseudomonas syringae. Society 2005, 18, 682-693. [CrossRef]

10. Torres, M.; Reina, J.C.; Fuentes-Monteverde, J.C.; Fernandez, G.; Rodriguez, J.; Jiménez, C.; Llamas, I. AHL-lactonase expression in three marine emerging pathogenic Vibrio spp. reduces virulence and mortality in brine shrimp (Artemia salina) and Manila clam (Venerupis philippinarum). PLoS ONE 2018, 13, e0195176. [CrossRef]

11. Torres, M.; Dessaux, Y.; Llamas, I. Saline Environments as a Source of Potential Quorum Sensing Disruptors to Control Bacterial Infections: A Review. Mar. Drugs 2019, 17, 191. [CrossRef]

12. Jayaraman, A.; Wood, T.K. Bacterial Quorum Sensing: Signals, Circuits, and Implications for Biofilms and Disease. Annu. Rev. Biomed. Eng. 2008, 10, 145-167. [CrossRef]

13. Soukarieh, F.; Williams, P.; Stocks, M.J.; Cámara, M. Pseudomonas aeruginosa Quorum Sensing Systems as Drug Discovery Targets: Current Position and Future Perspectives. J. Med. Chem. 2018, 61, 10385-10402. [CrossRef]

14. Grandclément, C.; Tannières, M.; Moréra, S.; Dessaux, Y.; Faure, D. Quorum quenching: Role in nature and applied developments. FEMS Microbiol. Rev. 2016, 40, 86-116. [CrossRef]

15. Bzdrenga, J.; Daudé, D.; Rémy, B.; Jacquet, P.; Plener, L.; Elias, M.; Chabrière, E. Biotechnological applications of quorum quenching enzymes. Chem. Biol. Interact. 2017, 267, 104-115. [CrossRef]

16. Uroz, S.; Dessaux, Y.; Oger, P. Quorum sensing and quorum quenching: The Yin and Yang of bacterial communication. ChemBioChem 2009, 10, 205-216. [CrossRef]

17. Jiang, Q.; Chen, J.; Yang, C.; Yin, Y.; Yao, K.; Song, D. Quorum Sensing: A Prospective Therapeutic Target for Bacterial Diseases. Biomed Res. Int. 2019, 2019, 2015978. [CrossRef]

18. Fetzner, S. Quorum quenching enzymes. J. Biotechnol. 2014, 201, 2-14. [CrossRef]

19. Dong, Y.-H.; Wang, L.-H.; Zhang, L.-H. Quorum-quenching microbial infections: Mechanisms and implications. Philos. Trans. R. Soc. B Biol. Sci. 2007, 362, 1201-1211. [CrossRef]

20. Chen, F.; Gao, Y.; Chen, X.; Yu, Z.; Li, X. Quorum quenching enzymes and their application in degrading signal molecules to block quorum sensing-dependent infection. Int. J. Mol. Sci. 2013, 14, 17477-17500. [CrossRef]

21. Ban, H.; Chai, X.; Lin, Y.; Zhou, Y.; Peng, D.; Zhou, Y.; Zou, Y.; Yu, Z.; Sun, M. Transgenic Amorphophallus konjac expressing synthesized acyl-homoserine lactonase (aiiA) gene exhibit enhanced resistance to soft rot disease. Plant Cell Rep. 2009, 28, 1847-1855. [CrossRef] [PubMed]

22. Torres, M.; Uroz, S.; Salto, R.; Fauchery, L.; Quesada, E.; Llamas, I. HqiA, a novel quorum-quenching enzyme which expands the AHL lactonase family. Sci. Rep. 2017, 7, 943. [CrossRef] [PubMed]

23. Molina, L.; Constantinescu, F.; Michel, L.; Reimmann, C.; Duffy, B.; Défago, G. Degradation of pathogen quorum-sensing molecules by soil bacteria: A preventive and curative biological control mechanism. FEMS Microbiol. Ecol. 2003, 45, 71-81. [CrossRef]

24. Reina, J.C.; Torres, M.; Llamas, I. Stenotrophomonas maltophilia AHL-degrading strains isolated from marine invertebrate microbiota attenuate the virulence of Pectobacterium carotovorum and Vibrio corallilyticus. Mar. Biotechnol. 2019, 21, 276-290. [CrossRef]

25. Dong, Y.H.; Xu, J.L.; Li, X.Z.; Zhang, L.H. AiiA, an enzyme that inactivates the acylhomoserine lactone quorum-sensing signal and attenuates the virulence of Erwinia carotovora. Proc. Natl. Acad. Sci. USA 2000, 97, 3526-3531. [CrossRef]

26. Liu, N.; Yu, M.; Zhao, Y.; Cheng, J.; An, K.; Zhang, X.H. PfmA, a novel quorum-quenching N-acylhomoserine lactone acylase from Pseudoalteromonas flavipulchra. Microbiology 2017, 163, 1389-1398. [CrossRef]

27. Vinoj, G.; Vaseeharan, B.; Thomas, S.; Spiers, A.J.; Shanthi, S. Quorum-Quenching Activity of the AHL-Lactonase from Bacillus licheniformis DAHB1 Inhibits Vibrio Biofilm Formation In Vitro and Reduces Shrimp Intestinal Colonisation and Mortality. Mar. Biotechnol. 2014, 16, 707-715. [CrossRef] 
28. Hraiech, S.; Hiblot, J.; Lafleur, J.; Lepidi, H.; Papazian, L.; Rolain, J.M.; Raoult, D.; Elias, M.; Silby, M.W.; Bzdrenga, J.; et al. Inhaled lactonase reduces Pseudomonas aeruginosa quorum sensing and mortality in rat pneumonia. PLoS ONE 2014, 9 , e107125. [CrossRef]

29. Mion, S.; Rémy, B.; Plener, L.; Brégeon, F.; Chabrière, E.; Daudé, D. Quorum Quenching Lactonase Strengthens Bacteriophage and Antibiotic Arsenal Against Pseudomonas aeruginosa Clinical Isolates. Front. Microbiol. 2019, 10, 2049. [CrossRef]

30. Bhardwaj, A.K.; Vinothkumar, K.; Rajpara, N. Bacterial Quorum Sensing Inhibitors: Attractive Alternatives for Control of Infectious Pathogens Showing Multiple Drug Resistance. Recent Pat. Antiinfect. Drug Discov. 2013, 8, 68-83. [CrossRef]

31. Yates, E.A.; Philipp, B.; Buckley, C.; Atkinson, S.; Chhabra, S.R.; Sockett, R.E.; Goldner, M.; Dessaux, Y.; Cámara, M.; Smith, $\mathrm{H}$; ; et al. N-acylhomoserine lactones undergo lactonolysis in a $\mathrm{pH}-$, temperature-, and acyl chain length-dependent manner during growth of Yersinia pseudotuberculosis and Pseudomonas aeruginosa. Infect. Immun. 2002, 70, 5635-5646. [CrossRef] [PubMed]

32. Bhatnagar, I.; Kim, S.K. Immense essence of excellence: Marine microbial bioactive compounds. Mar. Drugs 2010, 8, $2673-2701$. [CrossRef] [PubMed]

33. Romero, M.; Martin-Cuadrado, A.B.; Otero, A. Determination of whether quorum quenching is a common activity in marine bacteria by analysis of cultivable bacteria and metagenomic sequences. Appl. Environ. Microbiol. 2012, 78, 6345-6348. [CrossRef] [PubMed]

34. Romero, M.; Martin-Cuadrado, A.B.; Roca-Rivada, A.; Cabello, A.M.; Otero, A. Quorum quenching in cultivable bacteria from dense marine coastal microbial communities. FEMS Microbiol. Ecol. 2011, 75, 205-217. [CrossRef]

35. Linthorne, J.S.; Chang, B.J.; Flematti, G.R.; Ghisalberti, E.L.; Sutton, D.C. A Direct Pre-screen for Marine Bacteria Producing Compounds Inhibiting Quorum Sensing Reveals Diverse Planktonic Bacteria that are Bioactive. Mar. Biotechnol. 2014, 17, 33-42. [CrossRef]

36. Torres, M.; Romero, M.; Prado, S.; Dubert, J.; Tahrioui, A.; Otero, A.; Llamas, I. N-acylhomoserine lactone-degrading bacteria isolated from hatchery bivalve larval cultures. Microbiol. Res. 2013, 168, 547-554. [CrossRef]

37. Torres, M.; Rubio-Portillo, E.; Antón, J.; Ramos-Esplá, A.A.; Quesada, E.; Llamas, I. Selection of the N-acylhomoserine lactonedegrading bacterium Alteromonas stellipolaris PQQ-42 and of its potential for biocontrol in aquaculture. Front. Microbiol. 2016, 7, 646. [CrossRef]

38. León-Palmero, E.; Joglar, V.; Álvarez, P.A.; Martín-Platero, A.; Llamas, I.; Reche, I. Diversity and antimicrobial potential in sea anemone and holothurian microbiomes. PLoS ONE 2018, 13, e0196178. [CrossRef]

39. Reina, J.C.; Pérez-Victoria, I.; Martín, J.; Llamas, I. A quorum-sensing inhibitor strain of Vibrio alginolyticus blocks Qs-controlled phenotypes in Chromobacterium violaceum and Pseudomonas aeruginosa. Mar. Drugs 2019, 17, 494. [CrossRef]

40. Zhao, J.; Li, X.; Hou, X.; Quan, C.; Chen, M. Widespread Existence of Quorum Sensing Inhibitors in Marine Bacteria: Potential Drugs to Combat Pathogens with Novel Strategies. Mar. Drugs 2019, 17, 275. [CrossRef]

41. Chen, J.; Wang, B.; Lu, Y.; Guo, Y.; Sun, J.; Wei, B.; Zhang, H.; Wang, H. Quorum Sensing Inhibitors from Marine Microorganisms and Their Synthetic Derivatives. Mar. Drugs 2019, 17, 80. [CrossRef] [PubMed]

42. Richter, M.; Rosselló-Móra, R. Shifting the genomic gold standard for the prokaryotic species definition. Proc. Natl. Acad. Sci. USA 2009, 106, 19126-19131. [CrossRef] [PubMed]

43. Deschaght, P.; Janssens, M.; Vaneechoutte, M.; Wauters, G. Psychrobacter isolates of human origin, other than Psychrobacter phenylpyruvicus, are predominantly Psychrobacter faecalis and Psychrobacter pulmonis, with emended description of $P$. faecalis. Int. J. Syst. Evol. Microbiol. 2012, 62, 671-674. [CrossRef]

44. Bowman, J.P.; McCammon, S.A.; Brown, M.V.; Nichols, D.S.; McMeekin, T.A. Diversity and association of psychrophilic bacteria in Antarctic sea ice. Appl. Environ. Microbiol. 1997, 63, 3068-3078. [CrossRef]

45. Santiago, M.; Ramírez-Sarmiento, C.A.; Zamora, R.A.; Parra, L.P. Discovery, Molecular Mechanisms, and Industrial Applications of Cold-Active Enzymes. Front. Microbiol. 2016, 7, 1408. [CrossRef]

46. Raveendran, S.; Parameswaran, B.; Ummalyma, S.B.; Abraham, A.; Mathew, A.K.; Madhavan, A.; Rebello, S.; Pandey, A. Applications of Microbial Enzymes in Food Industry. Food Technol. Biotechnol. 2018, 56, 16-30. [CrossRef] [PubMed]

47. Bruno, S.; Coppola, D.; di Prisco, G.; Giordano, D.; Verde, C. Enzymes from Marine Polar Regions and Their Biotechnological Applications. Mar. Drugs 2019, 17, 544. [CrossRef] [PubMed]

48. Margesin, R.; Feller, G. Biotechnological applications of psychrophiles. Environ. Technol. 2010, 31, 835-844. [CrossRef] [PubMed]

49. Feller, G. Psychrophilic Enzymes: From Folding to Function and Biotechnology. Scientifica 2013, 2013, 512840. [CrossRef]

50. Wang, Y.; Hou, Y.; Nie, P.; Wang, Y.; Ren, X.; Wei, Q.; Wang, Q. A Novel Cold-Adapted and Salt-Tolerant RNase R from Antarctic Sea-Ice Bacterium Psychrobacter sp. ANT206. Molecules 2019, 24, 2229. [CrossRef]

51. Wu, G.; Zhang, X.; Wei, L.; Wu, G.; Kumar, A.; Mao, T.; Liu, Z. A cold-adapted, solvent and salt tolerant esterase from marine bacterium Psychrobacter pacificensis. Int. J. Biol. Macromol. 2015, 81, 180-187. [CrossRef] [PubMed]

52. Zhang, Y.; Ji, F.; Wang, J.; Pu, Z.; Jiang, B.; Bao, Y. Purification and characterization of a novel organic solvent-tolerant and cold-adapted lipase from Psychrobacter sp. ZY124. Extremophiles 2018, 22, 287-300. [CrossRef] [PubMed]

53. Gutiérrez-Barranquero, J.A.; Reen, F.J.; Parages, M.L.; McCarthy, R.; Dobson, A.D.W.; O'Gara, F. Disruption of N-acyl-homoserine lactone-specific signalling and virulence in clinical pathogens by marine sponge bacteria. Microb. Biotechnol. 2019, 12, 1049-1063. [CrossRef] [PubMed]

54. Li, H.; Lee, B.-C.; Kim, T.-S.; Bae, K.-S.; Hong, J.; Choi, S.-H.; Bao, B.; Jung, J.-H. Bioactive Cyclic Dipeptides from a Marine Sponge-Associated Bacterium, Psychrobacter sp. Biomol. Ther. 2008, 16, 356-363. [CrossRef] 
55. Huang, J.J.; Han, J.; Zhang, L.; Leadbetter, J.R. Utilization of Acyl-Homoserine Lactone Quorum Signals for Growth by a Soil Pseudomonad and Pseudomonas aeruginosa PAO1. Appl. Environ. Microbiol. 2003, 69, 5941-5949. [CrossRef]

56. Nathwani, D.; Raman, G.; Sulham, K.; Gavaghan, M.; Menon, V. Clinical and economic consequences of hospital-acquired resistant and multidrug-resistant Pseudomonas aeruginosa infections: A systematic review and meta-analysis. Antimicrob. Resist. Infect. Control 2014, 3, 32. [CrossRef]

57. Pachori, P.; Gothalwal, R.; Gandhi, P. Emergence of antibiotic resistance Pseudomonas aeruginosa in intensive care unit; a critical review. Genes Dis. 2019, 6, 109-119. [CrossRef]

58. Winzer, K.; Falconer, C.; Garber, N.C.; Diggle, S.P.; Camara, M.; Williams, P. The Pseudomonas aeruginosa lectins PA-IL and PA-IIL are controlled by quorum sensing and by RpoS. J. Bacteriol. 2000, 182, 6401-6411. [CrossRef]

59. Daniels, R.; Vanderleyden, J.; Michiels, J. Quorum sensing and swarming migration in bacteria. FEMS Microbiol. Rev. 2004, 28, 261-289. [CrossRef]

60. Girard, L. Quorum sensing in Vibrio spp.: The complexity of multiple signalling molecules in marine and aquatic environments. Crit. Rev. Microbiol. 2019, 45, 451-471. [CrossRef]

61. Liu, J.; Fu, K.; Wu, C.; Qin, K.; Li, F.; Zhou, L. “In-Group” communication in marine Vibrio: A review of N-Acyl Homoserine Lactones-Driven Quorum Sensing. Front. Cell. Infect. Microbiol. 2018, 8, 139. [CrossRef] [PubMed]

62. Chan, K.G.; Yin, W.F.; Sam, C.K.; Koh, C.L. A novel medium for the isolation of N-acylhomoserine lactone-degrading bacteria. J. Ind. Microbiol. Biotechnol. 2009, 36, 247-251. [CrossRef] [PubMed]

63. Defoirdt, T.; Bossier, P.; Sorgeloos, P.; Verstraete, W. The impact of mutations in the quorum sensing systems of Aeromonas hydrophila, Vibrio anguillarum and Vibrio harveyi on their virulence towards gnotobiotically cultured Artemia franciscana. Environ. Microbiol. 2005, 7, 1239-1247. [CrossRef]

64. Santhakumari, S.; Nilofernisha, N.M.; Ponraj, J.G.; Pandian, S.K.; Ravi, A.V. In vitro and in vivo exploration of palmitic acid from Synechococcus elongatus as an antibiofilm agent on the survival of Artemia franciscana against virulent vibrios. J. Invertebr. Pathol. 2017, 150, 21-31. [CrossRef]

65. Kalia, V.C.; Patel, S.K.S.; Kang, Y.C.; Lee, J.K. Quorum sensing inhibitors as antipathogens: Biotechnological applications. Biotechnol. Adv. 2019, 37, 68-90. [CrossRef]

66. Natrah, F.M.I.; Defoirdt, T.; Sorgeloos, P.; Bossier, P. Disruption of Bacterial Cell-to-Cell Communication by Marine Organisms and its Relevance to Aquaculture. Mar. Biotechnol. 2011, 13, 109-126. [CrossRef] [PubMed]

67. See-Too, W.S.; Convey, P.; Pearce, D.A.; Chan, K.-G. Characterization of a novel N-acylhomoserine lactonase, AidP, from Antarctic Planococcus sp. Microb. Cell Fact. 2018, 17, 179. [CrossRef]

68. Fan, X.; Liang, M.; Wang, L.; Chen, R.; Li, H.; Liu, X. Aii810, a Novel Cold-Adapted N-Acylhomoserine Lactonase Discovered in a Metagenome, Can Strongly Attenuate Pseudomonas aeruginosa Virulence Factors and Biofilm Formation. Front. Microbiol. 2017, 8, 1950. [CrossRef] [PubMed]

69. Shaw, P.D.; Ping, G.; Daly, S.L.; Cha, C.; Cronan, J.E.; Rinehart, K.L.; Farrand, S.K. Detecting and characterizing N-acyl-homoserine lactone signal molecules by thin-layer chromatography. Proc. Natl. Acad. Sci. USA 1997, 94, 6036-6041. [CrossRef]

70. Mcclean, K.H.; Winson, M.K.; Fish, L.; Taylor, A.; Chhabra, S.R.; Camara, M.; Daykin, M.; John, H.; Swift, S.; Bycroft, B.W.; et al. Quorum sensing and Chromobacterium violaceum: Exploitation of violacein production and inhibition for the detection of $\mathrm{N}$-acyl homoserine lactones. Microbiology 1997, 143, 3703-3711. [CrossRef]

71. Morohoshi, T.; Kato, M.; Fukamachi, K.; Kato, N.; Ikeda, T. N-Acylhomoserine lactone regulates violacein production in Chromobacterium violaceum type strain ATCC 12472. FEMS Microbiol. Lett. 2008, 279, 124-130. [CrossRef] [PubMed]

72. Winson, M.K.; Swift, S.; Fish, L.; Throup, J.P.; Jorgensen, F.; Chhabra, S.R.; Bycroft, B.W.; Williams, P.; Stewart, G.S.A. Construction and analysis of luxCDABE-based plasmid sensors for investigating $\mathrm{N}$-acyl homoserine lactone-mediated quorum sensing. FEMS Microbiol. Lett. 1998, 163, 185-192. [CrossRef] [PubMed]

73. Dubern, J.; Cigana, C.; De Simone, M.; Lazenby, J.; Juhas, M.; Schwager, S.; Bianconi, I.; Döring, G.; Eberl, L.; Williams, P.; et al. Integrated whole-genome screening for Pseudomonas aeruginosa virulence genes using multiple disease models reveals that pathogenicity is host specific. Environ. Microbiol. 2015, 17, 4379-4393. [CrossRef] [PubMed]

74. Rubio-Portillo, E.; Yarza, P.; Peñalver, C.; Ramos-Esplá, A.A.; Antón, J. New insights into Oculina patagonica coral diseases and their associated Vibrio spp. communities. ISME J. 2014, 8, 1794-1807. [CrossRef]

75. Marketon, M.M.; Gronquist, M.R.; Eberhard, A.; González, J.E. Characterization of the Sinorhizobium meliloti sinR/sinI locus and the production of novel N-acyl homoserine lactones. J. Bacteriol. 2002, 184, 5686-5695. [CrossRef]

76. Llamas, I.; Quesada, E.; Martínez-Cánovas, M.J.; Gronquist, M.; Eberhard, A.; González, J.E. Quorum sensing in halophilic bacteria: Detection of N-acyl-homoserine lactones in the exopolysaccharide-producing species of Halomonas. Extremophiles 2005, 9, 333-341. [CrossRef]

77. Uroz, S.; Chhabra, S.R.; Cámara, M.; Williams, P.; Oger, P.; Dessaux, Y. N-Acylhomoserine lactone quorum-sensing molecules are modified and degraded by Rhodococcus erythropolis W2 by both amidolytic and novel oxidoreductase activities. Microbiology 2005, 151, 3313-3322. [CrossRef]

78. Romero, M.; Muras, A.; Mayer, C.; Buján, N.; Magariños, B.; Otero, A. In vitro quenching of fish pathogen Edwardsiella tarda AHL production using marine bacterium Tenacibaculum sp. strain 20J cell extracts. Dis. Aquat. Organ. 2014, 108, 217-225. [CrossRef]

79. Marmur, J. A procedure for the isolation of deoxyribonucleic acid from micro-organisms. J. Mol. Biol. 1961, 3, 208-218. [CrossRef] 
80. Meier-Kolthoff, J.P.; Auch, A.F.; Klenk, H.P.; Göker, M. Genome sequence-based species delimitation with confidence intervals and improved distance functions. BMC Bioinform. 2013, 14, 60. [CrossRef]

81. Richter, M.; Rosselló-Móra, R.; Oliver Glöckner, F.; Peplies, J. JSpeciesWS: A web server for prokaryotic species circumscription based on pairwise genome comparison. Bioinformatics 2015, 32, 929-931. [CrossRef] [PubMed]

82. Aziz, R.K.; Bartels, D.; Best, A.; DeJongh, M.; Disz, T.; Edwards, R.A.; Formsma, K.; Gerdes, S.; Glass, E.M.; Kubal, M.; et al. The RAST Server: Rapid annotations using subsystems technology. BMC Genom. 2008, 9, 75. [CrossRef] [PubMed]

83. Overbeek, R.; Olson, R.; Pusch, G.D.; Olsen, G.J.; Davis, J.J.; Disz, T.; Edwards, R.A.; Gerdes, S.; Parrello, B.; Shukla, M.; et al. The SEED and the Rapid Annotation of microbial genomes using Subsystems Technology (RAST). Nucleic Acids Res. 2014, 42, D206-D214. [CrossRef] [PubMed]

84. Altschul, S.F.; Gish, W.; Miller, W.; Myers, E.W.; Lipman, D.J. Basic local alignment search tool. J. Mol. Biol. 1990, 215 , 403-410. [CrossRef]

85. Kumar, S.; Stecher, G.; Tamura, K. MEGA7: Molecular Evolutionary Genetics Analysis Version 7.0 for Bigger Datasets. Mol. Biol. Evol. 2016, 33, 1870-1874. [CrossRef] [PubMed]

86. Kelley, L.A.; Mezulis, S.; Yates, C.M.; Wass, M.N.; Sternberg, M.J.E. The Phyre2 web portal for protein modeling, prediction and analysis. Nat. Protoc. 2015, 10, 845-858. [CrossRef] [PubMed]

87. Woodcock, D.M.; Crowther, P.J.; Doherty, J.; Jefferson, S.; DeCruz, E.; Noyer-Weidner, M.; Smith, S.S.; Michael, M.Z.; Graham, M.W. Quantitative evaluation of Escherichia coli host strains for tolerance to cytosine methylation in plasmid and phage recombinants. Nucleic Acids Res. 1989, 17, 3469-3478. [CrossRef]

88. Bullock, O.W. XL1-Blue: A high efficiency plasmid transforming recA Escherichia coli strain with beta-galactosidase selection. Biotechniques 1987, 5, 376-379.

89. Lefebre, M.D.; Valvano, M.A. Construction and evaluation of plasmid vectors optimized for constitutive and regulated gene expression in Burkholderia cepacia complex isolates. Appl. Environ. Microbiol. 2002, 68, 5956-5964. [CrossRef]

90. Barrow, G.I.; Feltham, R.K.A. Cowan and Steel's Manual for the Identification of Medical Bacteria; Barrow, G.I., Feltham, R.K.A., Eds.; Cambridge University Press: Cambridge, UK, 1993.

91. Pikovskaya, R.I. Mobilization of phosphorus in soil in connection with the vital activity of some microbial species. Mikrobiologiya 1948, 17, 362-370.

92. Baird-Parker, A.C. A classification of micrococci and staphylococci based on physiological and biochemical tests. J. Gen. Microbiol. 1963, 30, 409-427. [CrossRef] [PubMed]

93. Mourey, A.; Kilbertus, G. Simple Media Containing Stabilized Tributyrin for Demonstrating Lipolytic Bacteria in Foods and Soils. J. Appl. Bacteriol. 1976, 40, 47-51. [CrossRef] [PubMed]

94. Choopun, N.; Louis, V.; Huq, A.; Colwell, R.R. Simple procedure for rapid identification of Vibrio cholerae from the aquatic environment. Appl. Environ. Microbiol. 2002, 68, 995-998. [CrossRef] [PubMed] 